\title{
Cytogenomic characteristics of murine breast cancer cell line JC
}

\author{
Shaymaa Azawi ${ }^{1}$, Martina Rincic ${ }^{2}$ and Thomas Liehr ${ }^{1 *}$ (D)
}

\begin{abstract}
Background: Breast cancer (BC), one of the most frequent human tumors, is genetically and histologically heterogeneous. Treatment options can be adapted according to BC subtype. Still, research is necessary to characterize BC biology better and to study potential new treatment options. Murine BC-cell lines can be used as model systems in this respect.

Results: Here for the first time murine BC-cell line JC was cytogenomically characterized as being complex rearranged and near-tetraploid. Multicolor banding and array comparative genomic hybridization were applied and the result was in silico translated to the human genome.
\end{abstract}

Conclusions: Even though being commercially available, cell line JC was yet not much included in BC-research, most likely due to a lack of cytogenomic data. Thus, here comprehensive data is provided on chromosomal aberrations, genomic imbalances and involved breakpoints of JC cell line. Also JC could be characterized as a model for BC of luminal B type, basal-like tumor rather than for luminal A type.

Keywords: Breast cancer, Murine cell line, JC, Murine multicolor banding (mcb), Array comparative genomic hybridization (aCGH)

\section{Introduction}

Breast cancer $(\mathrm{BC})$ is considered to be one of the most aggressive human cancer forms and is leading among cancer-related deaths, especially in females. Survival rates vary across countries depending on diagnostic regimens, awareness of and possibilities to treat this disease $[1,2]$. Factors like advanced age, low estrogen-levels, family history of cancer, and certain adverse gene mutations, as well as lifestyle influence incidence of this cancer type $[2,3]$. BCs are a heterogenic group of tumors, and thus divided into subtypes, according to their molecular profiles, morphology, and expression of specific biomarkers [4]. Therefore, each subtype has a different prognosis,

\footnotetext{
*Correspondence: Thomas.Liehr@med.uni-jena.de

${ }^{1}$ Institute of Human Genetics, Jena University Hospital, Friedrich Schiller University, Am Klinikum 1, 07747 Jena, Germany

Full list of author information is available at the end of the article

Abbreviations according to ISCN [37] are not included in this list.
}

a specific response to treatment and a defined clinical outcome $[4,5]$. All these go together with repeatedly observed aggressive clinical courses and limitations in breast cancer treatment [6]. BC biomarkers include oncogenes and tumor suppressor genes (TCGs), as well as their and related gene-products. Immunohistochemical markers for tumor cell surface or plasma, as well as for growth in this context are estrogen receptor, progesterone receptor, human epidermal growth factor receptor-2 (ERBB2/ HER-2) and epidermal growth factor receptor, cytokeratin 5 and/or nuclear protein Ki67 expression [1, 7]. Based on such expression profiles BC can be classified in (1) luminal A-like, (2) luminal B-like (HER2-positive or HER2-negative), (3) HER2-overexpressing, and (4) triplenegative subtypes $[4,7]$.

According to subtype, treatment regimens for $\mathrm{BC}$ are adapted [7, 8]. After initial surgery, being commonly applied for most BC subtypes chemo- and radio-therapeutic care follow, most of which have severe side effects.

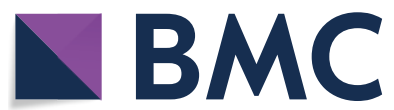

(c) The Author(s) 2021. This article is licensed under a Creative Commons Attribution 4.0 International License, which permits use, sharing, adaptation, distribution and reproduction in any medium or format, as long as you give appropriate credit to the original author(s) and the source, provide a link to the Creative Commons licence, and indicate if changes were made. The images or other third party material in this article are included in the article's Creative Commons licence, unless indicated otherwise in a credit line to the material. If material is not included in the article's Creative Commons licence and your intended use is not permitted by statutory regulation or exceeds the permitted use, you will need to obtain permission directly from the copyright holder. To view a copy of this licence, visit http://creativeco mmons.org/licenses/by/4.0/. The Creative Commons Public Domain Dedication waiver (http://creativecommons.org/publicdomain/ zero/1.0/) applies to the data made available in this article, unless otherwise stated in a credit line to the data. 
Thus, new types of medication being targeted only towards BC cells are still a pressing necessity [9]. The latter can be e.g. approached by including animal, especially murine models, in research to study biological pathways of $B C$ and $B C$ progression [10-12]. Even though murine cell lines are applied in ample research, still most of them are not characterized in detail genetically [1]. This is also valid for the here studied BC cell line JC, which was established in 1978 from a murine BC, developing spontaneously in a 1.5 years old female BALB/c mouse [13]. JC-cells show papillary adenocarcinoma morphology, and cytogenetics done in 1989 revealed only 26-100 chromosomes per cell, and 40 per cell being found in 28 of the 99 evaluated metaphases [14].

Molecular cytogenetics is considered the most practicable technique to characterize genetic alteration in cancer [15]. Thus, here for the first time, the murine BC cell line JC was studied in detail by multicolor-fluorescence in situ hybridization (FISH) using all murine whole chromosome painting (wcp) probes and FISH-based murine multicolor banding $(\mathrm{mcb})$ approach together with arraycomparative genomic hybridization (aCGH). The in silico translation performed on the data to determine the corresponding homologous genetic alterations in human BC was done as previously described [16].

\section{Materials and methods}

\section{Cell lines}

The cell line JC was obtained from American Type Culture Collection (ATCCR CRL-2116 ${ }^{\mathrm{TM}}$, Wesel, Germany). After being adherently grown in RPMI-1640 medium containing $10 \%$ fetal calf serum with recommended antibiotics, cells were cytogenetically prepared [17], and in parallel whole genomic DNA was extracted from the same passage of cells [16]. Molecular cytogenetic / FISH analyses (see below) on the cell line-derived chromosomes, and aCGH analyses on the extracted DNA (see below) were done. According to the ethical committee (medical faculty) and the Animal Experimentation Commission of the Friedrich Schiller University, there are no ethical agreements necessary for studies involving murine tumor cell lines like JC.

\section{Molecular cytogenetics}

FISH was performed as previously described [16] using whole chromosome paints ("SkyPaintTM DNA Kit M-10 for Mouse Chromosomes", Applied Spectral Imaging, Edingen-Neckarhausen, Germany) for multicolor-FISH (mFISH), and murine chromosome-specific multicolor banding (mcb) probe mixes for FISH-banding [18]. At least 30 metaphases were documented and analyzed for each probe set (Zeiss Axioplan microscopy, equipped with ISIS software (MetaSystems, Altlussheim,
Germany). Array-based comparative genomic hybridization $(\mathrm{aCGH})$ was done according to standard procedures by "SurePrint G3 Mouse CGH Microarray, $4 \times 180$ K" (Agilent Technologies) [16].

\section{Data analysis}

Imbalances and breakpoints being observed in JC were determined according to aCGH and mcb data, and aligned to human homologous regions using Ensembl and the UCSC Genome Browser, as previously described [19]. The obtained data were compared to genetic changes known from human BCs according to literature $[7,20-32]$.

\section{Results}

After wcp-based mFISH analyses, JC presented as relatively stable, hypo-tetraploid cell line with 64-66 chromosomes (result not shown). Overall there were 3 clones, which differed only in few alterations.

Clone 1 was considered as ancestor clone and present in $\sim 17 \%$ of the analyzed cells; karyotype: 64-66<4n>, XXX, -X, del(1)(E2), dic (2;9)(A1;A1),-3,$4, \operatorname{del}(5)(\mathrm{B}), \operatorname{der}(6)(: 14 \mathrm{~B} \rightarrow 14 \mathrm{~A} 1:: 6 \mathrm{~A} 1 \rightarrow 6 \mathrm{~B} 3:: 6 \mathrm{~B} 3 \rightarrow 6 \mathrm{~B}$ $1:: 6 \mathrm{~B} 1 \rightarrow 6 \mathrm{~B} 3:: 6 \mathrm{~B} 3 \rightarrow 6 \mathrm{~B} 1:: 6 \mathrm{~B} 1 \rightarrow 6 \mathrm{~B} 3:: 16 \mathrm{C} 1 \rightarrow 16 \mathrm{qter})$,$7, \operatorname{idic}(8)(\mathrm{A} 1 ; A 1), \operatorname{dic}(9 ; 13)(: 13 \mathrm{~A} 5->13 \mathrm{~A} 5::: 9 \mathrm{~A} 1 \rightarrow 9 \mathrm{q}$ ter),-10,-12,+13,-14,-16,-17,-18,-19.

Clone $2(53.3 \%)$ was present in $\sim 53 \%$ had the same karyotype shown in Fig. 1 as 64-66<4n $>$,idem, $\mathrm{XX},-\mathrm{X}$,$\mathrm{X}$,idem,t(3;14)(H4;D1), +6,+15,dup(17)(A2D1).

Clone 3 ( $30 \%$ of the cells) had the karyotype: 64-66<4n>idem, XX, der $(X)(X ; ?)($ pter $\rightarrow$ A6::? $),-X, t(3 ; 14)$ $(\mathrm{H} 4 ; \mathrm{D} 1),+6, \operatorname{der}(?)(? ; 11)(\mathrm{pter} \rightarrow \mathrm{A} 1:: \mathrm{E} 1 \rightarrow \mathrm{qter}), \operatorname{del}(13)$ (A5),dup(17)(A2D1), +15 .

Overall, FISH-data was in agreement with the aCGH results and copy number alterations and breakpoints are summarized in Fig. 2a. An in-silico-translation of those results to the human genome (only imbalances larger than 3.5 megabase pairs were included) identified the corresponding homologous region in the human genome (Fig. 2b). Genomic details are given in Additional file 1: Table S1.

The corresponding homologous regions for the cell line were compared with common imbalances in human $\mathrm{BC}$, and this revealed copy number variations in regions known to harbor oncogenes and tumor suppressor genes (TSG) with an overlap of $40 \%$ (Table 1). The breakpoints of the cell line compared with the chromosomal breaks of human BC overlap to $56 \%$ (Table 2). Genetic alterations in cell line JC correlated best with the subtype for human $\mathrm{BC}$ acc. to Horlings et al. [32] with basal-like (50\%) and luminal B type tumors (67\%); no correlation was found with human luminal A type BCs (Table 3). 


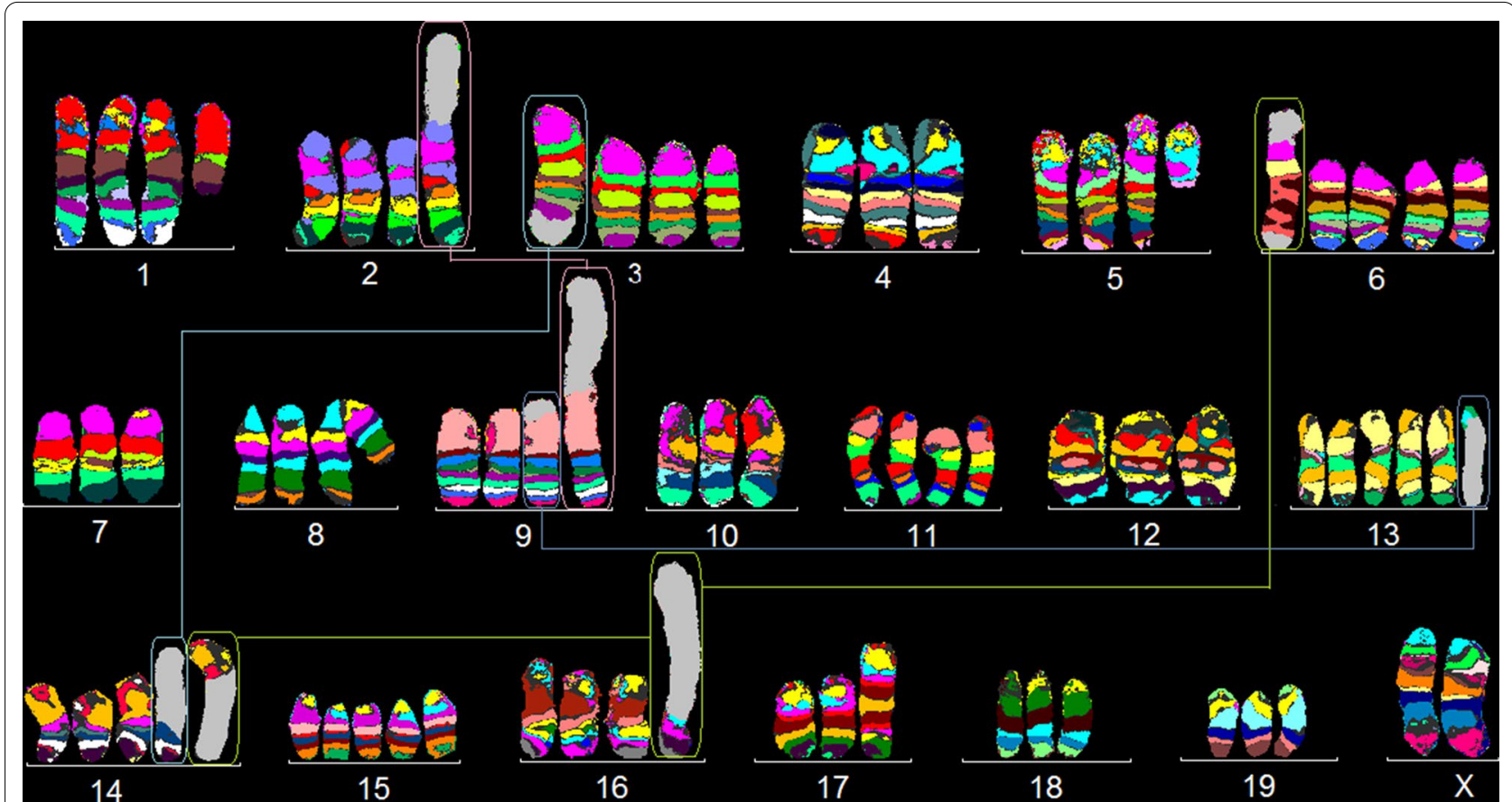

Fig. 1 Murine multicolor banding (mcb) was applied on chromosomes of the JC cell line. This figure depicts the summary of 20 chromosome-specific FISH-experiments as typical pseudocolor banding. Derivative chromosomes consisting of different chromosomes are highlighted by frames and shown twice or thrice in this summarizing karyogram

\section{Discussion}

$\mathrm{BC}$ is one of most frequent tumors in females, genetically heterogeneous and with an often very aggressive course. Therefore, still basic research is necessary to understand better its biology and to find more efficient treatment strategies. Accordingly, especially murine tumor cell lines are favorite model systems to perform basic research studies, as well as such towards testing of new medications [8, 33]. Our group characterized already several murine tumor cell lines by the same test strategy as applied here, and thus delivered previously not available but urgently necessary genetic basic data, including chromosome numbers, observable breakpoints and copy number changes $[1,16,17,19,34,35]$. Here a commercially available murine $\mathrm{BC}$-cell line was characterized for the first time, cell line JC, which was yet rarely used in research. It may be speculated that this was in major parts due to the fact that there was no genetic information available, yet. This gap was closed by the present study now.

JC cell line presents a near-tetraploidy karyotype, which is typically observable, especially in human [36], however, only present in about $50 \%$ of murine tumor cell lines [1, 16, 17, 19, 34, 35]. Polyploidy promotes malignant transformation of mammary cells and increases cell resistance to drugs [36]; still, it is also a known adaptation of cells to cell culture conditions. In case of JC cell line the only available previous cytogenetic characterization dates back to 1989; at that stage the cell line was extremely chromosomally instable with chromosome numbers reported between 28 and 99 . As $\sim 30 \%$ of the cells had modal chromosome numbers of 40 [14] it must be suggested that since that time a stabilization of the karyotype by tetraploidization took place. However, structurally rearranged chromosomes were not duplicated, as observed in other tetraploid BC cell lines [1]. For observed copy number alterations gain of copy numbers was observed for $M Y C$ and loss of heterozygosity for tumor suppressor genes $M S H 2, P T E N$ and $B R C A 2$ were determined here.

Overall, murine cell line JC can has here been genetically characterized and it could be shown to be suited 


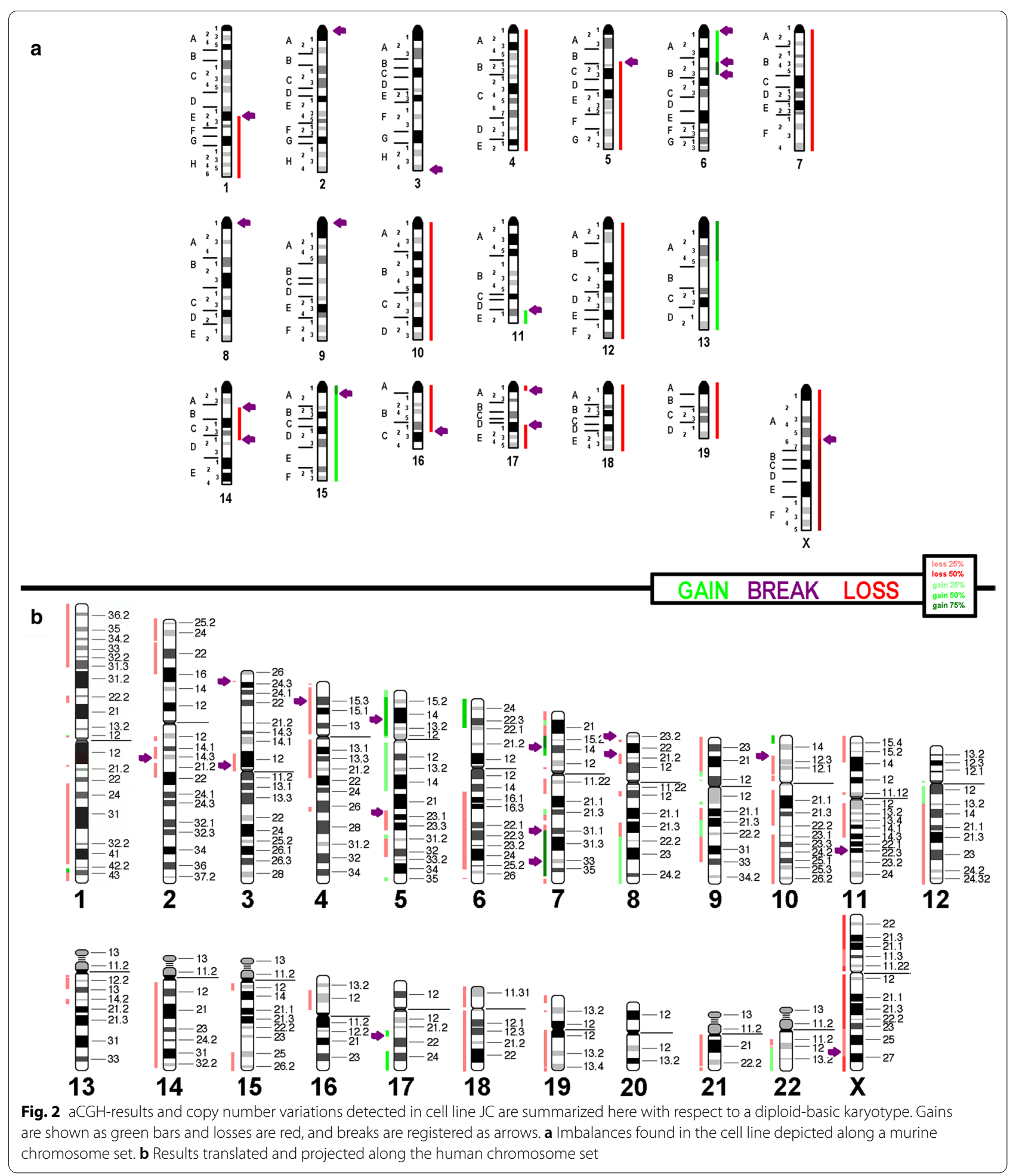


Table 1 Oncogenes and tumor suppressor genes (TSG), related to human $B C[20,21]$ and their involvement in gains or loss of copy numbers in JC cell line

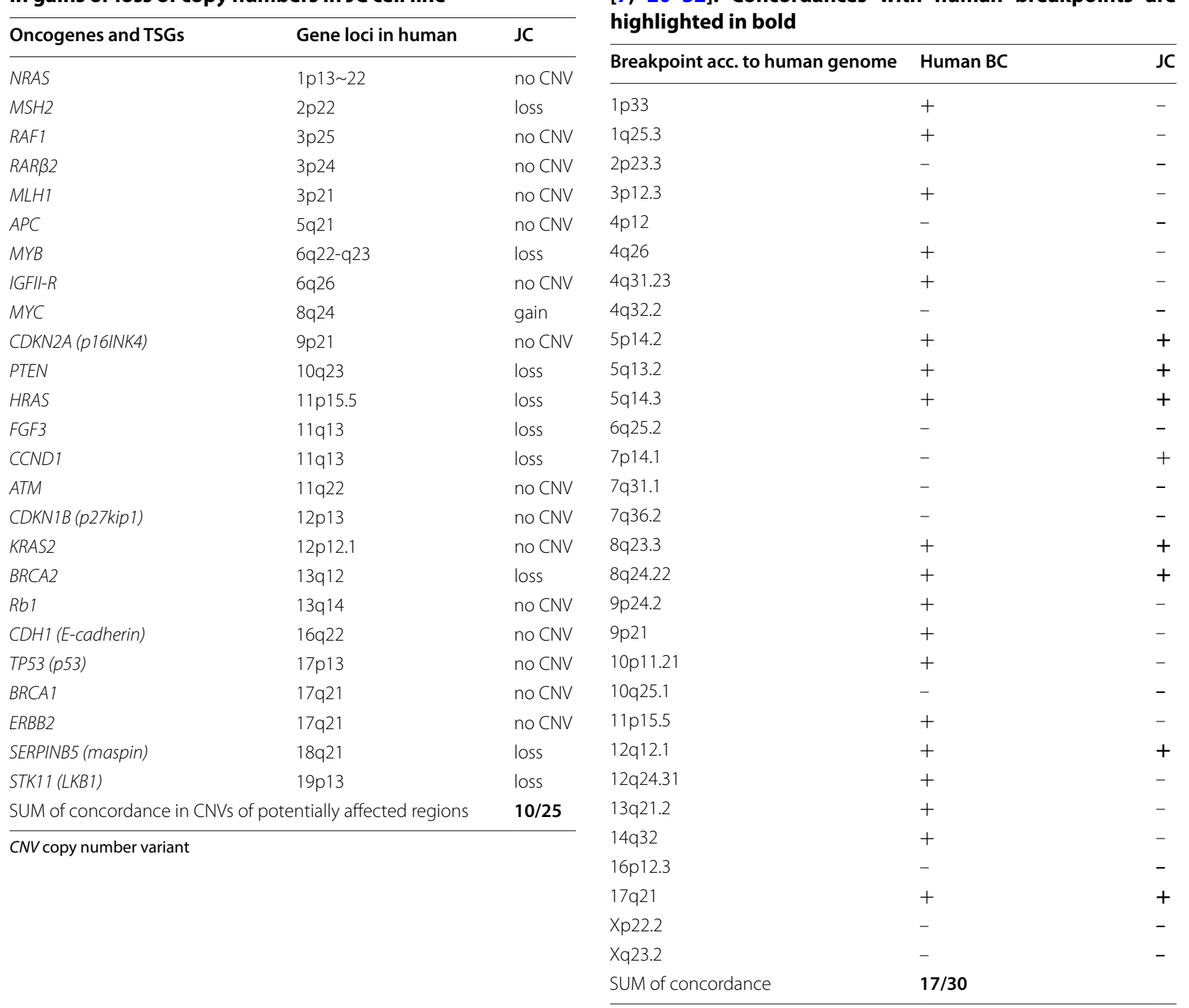

Table 2 Breakpoints in JC compared to the observed acquired breaks in human BCs according to the literature [7, 20-32]: Concordances with human breakpoints are highlighted in bold

$+$ 
Table 3 Copy number alterations associated with molecular subtypes of human $\mathrm{BC}$, according to [32], with the copy number variants (CNVs) in cell lines JC

\begin{tabular}{|c|c|c|}
\hline \multicolumn{3}{|l|}{ DNA changes } \\
\hline In BC subtypes & Human BC & JC \\
\hline \multicolumn{3}{|l|}{ HER2+/ERBB2 } \\
\hline 17q11.1 12 & gain & no CNV \\
\hline 17q21.31 23.2 & gain & $\begin{array}{l}\text { gain but } \\
\text { ERBB2 is not } \\
\text { included }\end{array}$ \\
\hline SUM of concordance & & $0 / 2$ \\
\hline \multicolumn{3}{|l|}{ Basal-like tumors } \\
\hline $4 p 15.31$ & loss & loss \\
\hline $5 q 12.3 \sim 13.2$ & loss & gain \\
\hline $5 q 33.1$ & loss & loss \\
\hline $6 p 12.3$ & gain & no CNV \\
\hline $6 p 21.1 \sim 23$ & gain & gain \\
\hline $8 q 24.21 \sim 24.22$ & gain & gain \\
\hline 10p12.33 14 & gain & loss \\
\hline $10 q 23.33$ & loss & loss \\
\hline $12 q 13.13$ & loss & gain \\
\hline $12 q 13.3$ & loss & loss \\
\hline $15 q 15.1$ & loss & no CNV \\
\hline $15 q 21.1$ & loss & no CNV \\
\hline SUM of concordance & & $6 / 12$ \\
\hline \multicolumn{3}{|l|}{ Luminal A } \\
\hline $1 \mathrm{q} 21.3$ & gain & no CNV \\
\hline $1 q 44$ & gain & loss \\
\hline $16 p 13.13$ & gain & no CNV \\
\hline 16p13.12 & gain & loss \\
\hline $16 q 11.2 \sim 13$ & loss & no CNV \\
\hline $16 q 22.1-24.1$ & loss & no CNV \\
\hline SUM of concordance & & $0 / 6$ \\
\hline \multicolumn{3}{|l|}{ Luminal B } \\
\hline $1 \mathrm{p} 31.3$ & loss & loss \\
\hline 8p21.2 & loss & loss \\
\hline $17 q 23.2$ & gain & loss \\
\hline SUM of concordance & & $2 / 3$ \\
\hline
\end{tabular}

Concordances with human CNVs are highlighted in bold

CNV copy number variant

as a model for $\mathrm{BC}$ of luminal $\mathrm{B}$ type, basal-like tumor. It seems to be not suited as luminal A type $\mathrm{BC}$ model.

\section{Supplementary information}

The online version contains supplementary material available https://doi. org/10.1186/s13039-020-00524-z.

Additional file 1: Table $\mathbf{S} 1$ The regions of gain and loss of copy numbers, as well of breakpoints of balanced rearrangements, observed in JC and the corresponding homologue regions in humans are listed as cytoband and position (GRCh37/hg19).
Abbreviations

aCGH: array comparative genomic hybridization; BC: breast cancer; CNV: copy number variant; FISH: fluorescence in situ hybridization; ISCN: International System for Human Cytogenomic Nomenclature; mcb: murine multicolor banding; mFISH: multicolor-fluorescence in situ hybridization; wcp: whole chromosome painting.

\section{Acknowledgements}

The technical support of Dr. Nadezda Kosyakova (Jena, Germany) is kindly acknowledged.

\section{Authors' contributions}

TL developed the idea for the study; SA did the FISH-studies; MR performed aCGH studies and did pre-evaluation; SA performed the overall data interpretation; TL and SA did final paper drafting; all authors agreed on final draft.

\section{Funding}

Open Access funding enabled and organized by Projekt DEAL. This research was funded by Grant \# 2013.032.1 of the Wilhelm Sander-Stiftung.

\section{Availability of data and materials}

All relevant data and material is included in this publication.

\section{Ethics approval and consent to participate}

According to the ethical committee (medical faculty) and the Animal Experimentation Commission of the Friedrich Schiller University, there are no ethical agreements necessary for studies involving murine tumor cell lines like JC.

\section{Consent for publication}

N.A.

\section{Competing interests}

The authors declare that they have no competing interests.

\section{Author details}

${ }^{1}$ Institute of Human Genetics, Jena University Hospital, Friedrich Schiller University, Am Klinikum 1, 07747 Jena, Germany. ${ }^{2}$ Croatian Institute for Brain Research, School of Medicine University of Zagreb, Salata 12, 10000 Zagreb, Croatia.

Received: 27 November 2020 Accepted: 22 December 2020

Published online: 01 February 2021

\section{References}

1. Azawi S, Liehr T, Rincic M, Manferrari M. Molecular cytogenomic characterization of the murine breast cancer cell lines C-127l, EMT6/P and TA3 Hauschka. Int J Mol Sci. 2020;21(13):4716. https://doi.org/10.3390/ijms2 1134716.

2. Shah R, Rosso K, Nathanson SD. Pathogenesis, prevention, diagnosis and treatment of breast cancer. World J Clin Oncol. 2014;5(3):283-98. https:// doi.org/10.5306/wjco.v5.i3.283.

3. Sun YS, Zhao Z, Yang ZN, Xu F, Lu HJ, Zhu ZY, Shi W, Jiang J, Yao PP, Zhu HP. Risk factors and preventions of breast cancer. Int J Biol Sci. 2017;13(11):1387-97. https://doi.org/10.7150/ijbs.21635.

4. Januškevičienè I, Petrikaite V. Heterogeneity of breast cancer: the importance of interaction between different tumor cell populations. Life Sci. 2019;239:117009. https://doi.org/10.1016/j.lfs.2019.117009.

5. Rouzier R, Perou CM, Symmans WF, Ibrahim N, Cristofanilli M, Anderson K, Hess KR, Stec J, Ayers M, Wagner P, Morandi P, Fan C, Rabiul I, Ross JS, Hortobagyi GN, Pusztai L. Breast cancer molecular subtypes respond differently to preoperative chemotherapy. Clin Cancer Res. 2005;11(16):5678-85. https://doi.org/10.1158/1078-0432.CCR-04-2421.

6. Feng Y, Spezia M, Huang S, Yuan C, Zeng Z, Zhang L, Ji X, Liu W, Huang B, Luo W, Liu B, Lei Y, Du S, Vuppalapati A, Luu HH, Haydon RC, He TC, Ren G. Breast cancer development and progression: risk factors, cancer stem cells, signaling pathways, genomics, and molecular pathogenesis. Genes Dis. 2018;5(2):77-106. https://doi.org/10.1016/j.gendi s.2018.05.001. 
7. Kikuchi-Koike R, Nagasaka K, Tsuda H, Ishii Y, Sakamoto M, Kikuchi Y, Fukui S, Miyagawa Y, Hiraike H, Kobayashi T, Kinoshita T, Kanai Y, Shibata T, Imoto I, Inazawa J, Matsubara O, Ayabe T. Array comparative genomic hybridization analysis discloses chromosome copy number alterations as indicators of patient outcome in lymph node-negative breast cancer. BMC Cancer. 2019;19(1):521. https://doi.org/10.1186/ s12885-019-5737-7.

8. Yersal O, Barutca S. Biological subtypes of breast cancer: prognostic and therapeutic implications. World J Clin Oncol. 2014;5(3):412-24. https:// doi.org/10.5306/wjco.v5.i3.412.

9. Raihan J, Ahmad U, Yong YK, Eshak Z, Othman F, Ideris A. Regression of solid breast tumours in mice by Newcastle disease virus is associated with production of apoptosis related-cytokines. BMC Cancer. 2019;19(1):315. https://doi.org/10.1186/s12885-019-5516-5.

10. Jones RA, Moorehead RA. Integrative analysis of copy number and gene expression data identifies potential oncogenic drivers that promote mammary tumor recurrence. Genes Chromosom Cancer. 2019;58(6):38191. https://doi.org/10.1002/gcc.22729.

11. Osborne C, Wilson P, Tripathy D. Oncogenes and tumor suppressor genes in breast cancer: potential diagnostic and therapeutic applications. Oncologist. 2004;9(4):361-77. https://doi.org/10.1634/theoncolog ist.9-4-361.

12. Wronski A, Arendt LM, Kuperwasser C. Humanization of the mouse mammary gland. Methods Mol Biol. 2015;1293:173-86. https://doi. org/10.1007/978-1-4939-2519-3_10.

13. Capone PM, Kadohama N, Chu TM. Immunotherapy in a spontaneously developed murine mammary carcinoma with syngeneic monoclonal antibody. Cancer Immunol Immunother. 1987;25(2):93-9. https://doi. org/10.1007/BF00199947.

14. Chao TY, Chu TM. Characterization of a new spontaneously developed murine mammary adenocarcinoma in syngeneic BALB/C hosts. Vitro Cell Dev Biol. 1989;25(7):621-6. https://doi.org/10.1007/BF02623632.

15. Patil Okaly GV, Panwar D, Lingappa KB, Kumari P, Anand A, Kumar P, Chikkalingaiah MH, Kumar RV. FISH and HER2/neu equivocal immunohistochemistry in breast carcinoma. Indian J Cancer. 2019;56(2):119-23. https ://doi.org/10.4103/ijc.IJC_333_18.

16. Kubicova E, Trifonov V, Borovecki F, Liehr T, Rincic M, Kosyakova N, Hussein SS. First molecular cytogenetic characterization of murine malignant mesothelioma cell line AE17 and in silico translation to the human genome. Curr Bioinform. 2017;12(1):11-8.

17. Rhode H, Liehr T, Kosyakova N, Rincic M, Azawi SSH. Molecular cytogenetic characterization of two murine colorectal cancer cell lines. OBM Genet. 2018;2(3):1803037. https://doi.org/10.21926/obm.genet.1803037.

18. Liehr T, Starke H, Heller A, Kosyakova N, Mrasek K, Gross M, Karst C, Steinhaeuser U, Hunstig F, Fickelscher I, Kuechler A, Trifonov V, Romanenko SA, Weise A. Multicolor fluorescence in situ hybridization (FISH) applied to FISH-banding. Cytogenet Genome Res. 2006;114(3-4):240-4. https://doi. org/10.1159/000094207.

19. Leibiger C, Kosyakova N, Mkrtchyan H, Glei M, Trifonov V, Liehr T. First molecular cytogenetic high resolution characterization of the $\mathrm{NIH}$ $3 T 3$ cell line by murine multicolor banding. J Histochem Cytochem. 2013;61(4):306-12. https://doi.org/10.1369/0022155413476868.

20. Hall JM, Zuppan PJ, Anderson LA, Huey B, Carter C, King MC. Oncogenes and human breast cancer. Am J Hum Genet. 1989;44(4):577-84.

21. Oliveira AM, Ross JS, Fletcher JA. Tumor suppressor genes in breast cancer: the gatekeepers and the caretakers. Am J Clin Pathol. 2005;124:S1628. https://doi.org/10.1309/5XW3L8LU445QWGQR.

22. Lebok P, Roming M, Kluth M, Koop C, Özden C, Taskin B, Hussein K, Lebeau A, Witzel I, Wölber L, Geist S, Paluchowski P, Wilke C, Heilenkötter U, Müller V, Schmalfeldt B, Simon R, Sauter G, Terracciano L, Krech RH, von der Assen A, Burandt E. p16 overexpression and 9p21 deletion are linked to unfavorable tumor phenotype in breast cancer. Oncotarget. 2016;7(49):81322-31. https://doi.org/10.18632/oncotarget.13227.

23. Lawrenson K, Kar S, McCue K, Kuchenbaeker K, Michailidou K, Tyrer J, Beesley J, Ramus SJ, Li Q, Delgado MK, Lee JM, Aittomäki K, Andrulis IL, Anton-Culver H, Arndt V, Arun BK, Arver B, Bandera EV, Barile M, Barkardottir RB, Barrowdale D, Beckmann MW, Benitez J, Berchuck A, Bisogna M, Bjorge L, Blomqvist C, Blot W, Bogdanova N, Bojesen A, Bojesen SE, Bolla MK, Bonanni B, Børresen-Dale AL, Brauch H, Brennan P, Brenner $H$, Bruinsma F, Brunet J, Buhari SA, Burwinkel B, Butzow R, Buys SS, Cai Q, Caldes T, Campbell I, Canniotto R, Chang-Claude J, Chiquette J, Choi JY,
Claes KB, GEMO Study Collaborators, Cook LS, Cox A, Cramer DW, Cross SS, Cybulski C, Czene K, Daly MB, Damiola F, Dansonka-Mieszkowska A, Darabi H, Dennis J, Devilee P, Diez O, Doherty JA, Domchek SM, Dorfling CM, Dörk T, Dumont M, Ehrencrona H, Ejlertsen B, Ellis S, EMBRACE, Engel C, Lee E, Evans DG, Fasching PA, Feliubadalo L, Figueroa J, Flesch-Janys D, Fletcher O, Flyger H, Foretova L, Fostira F, Foulkes WD, Fridley BL, Friedman E, Frost D, Gambino G, Ganz PA, Garber J, García-Closas M, Gentry-Maharaj A, Ghoussaini M, Giles GG, Glasspool R, Godwin AK, Goldberg MS, Goldgar DE, González-Neira A, Goode EL, Goodman MT, Greene MH, Gronwald J, Guénel P, Haiman CA, Hall P, Hallberg E, Hamann U, Hansen TV, Harrington PA, Hartman M, Hassan N, Healey S, Hereditary Breast and Ovarian Cancer Research Group Netherlands (HEBON), Heitz F, Herzog J, Høgdall E, Høgdall CK, Hogervorst FB, Hollestelle A, Hopper JL, Hulick PJ, Huzarski T, Imyanitov EN, KConFab Investigators, Australian Ovarian Cancer Study Group, Isaacs C, Ito H, Jakubowska A, Janavicius R, Jensen A, John EM, Johnson N, Kabisch M, Kang D, Kapuscinski M, Karlan BY, Khan S, Kiemeney LA, Kjaer SK, Knight JA, Konstantopoulou I, Kosma VM, Kristensen V, Kupryjanczyk J, Kwong A, de la Hoya M, Laitman Y, Lambrechts D, Le N, De Leeneer K, Lester J, Levine DA, Li J, Lindblom A, Long J, Lophatananon A, Loud JT, Lu K, Lubinski J, Mannermaa A, Manoukian S, Le Marchand L, Margolin S, Marme F, Massuger LF, Matsuo K, Mazoyer S, McGuffog L, McLean C, McNeish I, Meindl A, Menon U, Mensenkamp AR, Milne RL, Montagna M, Moysich KB, Muir K, Mulligan AM, Nathanson KL, Ness RB, Neuhausen SL, Nevanlinna H, Nord S, Nussbaum RL, Odunsi K, Offit K, Olah E, Olopade OI, Olson JE, Olswold C, O'Malley D, Orlow I, Orr N, Osorio A, Park SK, Pearce CL, Pejovic T, Peterlongo P, Pfeiler G, Phelan CM, Poole EM, Pylkäs K, Radice P, Rantala J, Rashid MU, Rennert G, Rhenius V, Rhiem K, Risch HA, Rodriguez G, Rossing MA, Rudolph A, Salvesen HB, Sangrajrang S, Sawyer EJ, Schildkraut JM, Schmidt MK, Schmutzler RK, Sellers TA, Seynaeve C, Shah M, Shen CY, Shu XO, Sieh W, Singer CF, Sinilnikova OM, Slager S, Song H, Soucy P, Southey MC, Stenmark-Askmalm M, Stoppa-Lyonnet D, Sutter C, Swerdlow A, Tchatchou S, Teixeira MR, Teo SH, Terry KL, Terry MB, Thomassen M, Tibiletti MG, Tihomirova L, Tognazzo S, Toland AE, Tomlinson I, Torres D, Truong T, Tseng CC, Tung N, Tworoger SS, Vachon C, van den Ouweland AM, van Doorn HC, van Rensburg EJ, Van't Veer LJ, Vanderstichele A, Vergote I, Vijai J, Wang Q, Wang-Gohrke S, Weitzel JN, Wentzensen N, Whittemore AS, Wildiers H, Winqvist R, Wu AH, Yannoukakos D, Yoon SY, Yu JC, Zheng W, Zheng Y, Khanna KK, Simard J, Monteiro AN, French JD, Couch FJ, Freedman ML, Easton DF, Dunning AM, Pharoah PD, Edwards SL, Chenevix-Trench G, Antoniou AC, Gayther SA. Functional mechanisms underlying pleiotropic risk alleles at the 19p13.1 breast-ovarian cancer susceptibility locus. Nat Commun. 2016;7:12675. https://doi.org/10.1038/ncomms12675.

24. Cheng TH, Thompson DJ, O'Mara TA, Painter JN, Glubb DM, Flach S, Lewis A, French JD, Freeman-Mills L, Church D, Gorman M, Martin L, National Study of Endometrial Cancer Genetics Group (NSECG), Hodgson S, Webb PM, Australian National Endometrial Cancer Study Group (ANECS), Attia J, Holliday EG, McEvoy M, Scott RJ, Henders AK, Martin NG, Montgomery GW, Nyholt DR, Ahmed S, Healey CS, Shah M, Dennis J, Fasching PA, Beckmann MW, Hein A, Ekici AB, Hall P, Czene K, Darabi H, Li J, DörkT, Dürst M, Hillemanns P, Runnebaum I, Amant F, Schrauwen S, Zhao H, Lambrechts D, Depreeuw J, Dowdy SC, Goode EL, Fridley BL, Winham SJ, Njølstad TS, Salvesen HB, Trovik J, Werner HM, Ashton K, Otton G, Proietto T, Liu T, Mints M, Tham E, RENDOCAS, Jun Li M, Yip SH, Wang J, Bolla MK, Michailidou K, Wang Q, Tyrer JP, Dunlop M, Houlston R, Palles C, Hopper $J$, AOCS Group, Peto J, Swerdlow AJ, Burwinkel B, Brenner H, Meindl A, Brauch H, Lindblom A, Chang-Claude J, Couch FJ, Giles GG, Kristensen VN, Cox A, Cunningham JM, Pharoah PDP, Dunning AM, Edwards SL, Easton DF, Tomlinson I, Spurdle AB. Five endometrial cancer risk loci identified through genome-wide association analysis. Nat Genet. 2016;48(6):66774. https://doi.org/10.1038/ng.3562.

25. Couch FJ, Gaudet MM, Antoniou AC, Ramus SJ, Kuchenbaecker KB, Soucy P, Beesley J, Chen X, Wang X, KirchhoffT, McGuffog L, Barrowdale D, Lee A, Healey S, Sinilnikova OM, Andrulis IL, OCGN, Ozcelik H, Mulligan AM, Thomassen M, Gerdes AM, Jensen UB, Skytte AB, Kruse TA, Caligo MA, von Wachenfeldt A, Barbany-Bustinza G, Loman N, Soller M, Ehrencrona $H$, Karlsson P, SWE-BRCA, Nathanson KL, Rebbeck TR, Domchek SM, Jakubowska A, Lubinski J, Jaworska K, Durda K, Zlowocka E, Huzarski T, Byrski T, Gronwald J, Cybulski C, Górski B, Osorio A, Durán M, Tejada MI, Benitez J, Hamann U, Hogervorst FB, HEBON, van Os TA, van Leeuwen FE, Meijers-Heijboer HE, Wijnen J, Blok MJ, Kets M, Hooning MJ, Oldenburg 
RA, Ausems MG, Peock S, Frost D, Ellis SD, Platte R, Fineberg E, Evans DG, Jacobs C, Eeles RA, Adlard J, Davidson R, Eccles DM, Cole T, Cook J, Paterson J, Brewer C, Douglas F, Hodgson SV, Morrison PJ, Walker L, Porteous ME, Kennedy MJ, Side LE, EMBRACE, Bove B, Godwin AK, Stoppa-Lyonnet D, GEMO Study Collaborators, Fassy-Colcombet M, Castera L, Cornelis F, Mazoyer S, Léoné M, Boutry-Kryza N, Bressac-de Paillerets B, Caron O, Pujol P, Coupier I, Delnatte C, Akloul L, Lynch HT, Snyder CL, Buys SS, Daly MB, Terry M, Chung WK, John EM, Miron A, Southey MC, Hopper $J \mathrm{~L}$, Goldgar DE, Singer CF, Rappaport C, Tea MK, Fink-Retter A, Hansen TV, Nielsen FC, Arason A, Vijai J, Shah S, Sarrel K, Robson ME, Piedmonte M, Phillips K, Basil J, Rubinstein WS, Boggess J, Wakeley K, Ewart-Toland A, Montagna M, Agata S, Imyanitov EN, Isaacs C, Janavicius R, Lazaro C, Blanco I, Feliubadalo L, Brunet J, Gayther SA, Pharoah PP, Odunsi KO, Karlan BY, Walsh CS, Olah E, Teo SH, Ganz PA, Beattie MS, van Rensburg EJ, Dorfling CM, Diez O, Kwong A, Schmutzler RK, Wappenschmidt B, Engel C, Meindl A, Ditsch N, Arnold N, Heidemann S, Niederacher D, PreislerAdams S, Gadzicki D, Varon-Mateeva R, Deissler H, Gehrig A, Sutter C, Kast K, Fiebig B, Heinritz W, Caldes T, de la Hoya M, Muranen TA, Nevanlinna H, Tischkowitz MD, Spurdle AB, Neuhausen SL, Ding YC, Lindor NM, Fredericksen Z, Pankratz VS, Peterlongo P, Manoukian S, Peissel B, Zaffaroni D, Barile M, Bernard L, Viel A, Giannini G, Varesco L, Radice P, Greene MH, Mai PL, Easton DF, Chenevix-Trench G, KConFab investigators, Offit K, Simard J, Consortium of Investigators of Modifiers of BRCA1/2. Common variants at the 19p13.1 and ZNF365 loci are associated with ER subtypes of breast cancer and ovarian cancer risk in BRCA1 and BRCA2 mutation carriers. Cancer Epidemiol Biomark Prev. 2012;21(4):645-57. https://doi. org/10.1158/1055-9965.EPI-11-0888.

26. de Kock L, Geoffrion D, Rivera B, Wagener R, Sabbaghian N, Bens S, Ellezam B, Bouron-Dal Soglio D, Ordóñez J, Sacharow S, Polo Nieto JF, Guillerman RP, Vujanic GM, Priest JR, Siebert R, Foulkes WD. Multiple DICER1-related tumors in a child with a large interstitial 14q32 deletion. Genes Chromosomes Cancer. 2018;57(5):223-30. https://doi.org/10.1002/ gcc.22523.

27. Lupicki K, Elifio-Esposito S, Fonseca AS, Weber SH, Sugita B, Langa BC, Pereira SRF, Govender D, Panieri E, Hiss DC, Abdul-Rasool S, Cavalli LR. Patterns of copy number alterations in primary breast tumors of South African patients and their impact on functional cellular pathways. Int J Oncol. 2018;53(6):2745-57. https://doi.org/10.3892/ijo.2018.4589.

28. Antoniou AC, Kuchenbaecker KB, Soucy P, Beesley J, Chen X, McGuffog L, Lee A, Barrowdale D, Healey S, Sinilnikova OM, Caligo MA, Loman N, Harbst K, Lindblom A, Arver B, Rosenquist R, Karlsson P, Nathanson K, Domchek S, RebbeckT, Jakubowska A, Lubinski J, Jaworska K, Durda K, Złowowcka-Perłowska E, Osorio A, Durán M, Andrés R, Benítez J, Hamann U, Hogervorst FB, van Os TA, Verhoef S, Meijers-Heijboer HE, Wijnen J, Gómez Garcia EB, Ligtenberg MJ, Kriege M, Collée JM, Ausems MG, Oosterwijk JC, Peock S, Frost D, Ellis SD, Platte R, Fineberg E, Evans DG, Lalloo F, Jacobs C, Eeles R, Adlard J, Davidson R, Cole T, Cook J, Paterson J, Douglas F, Brewer C, Hodgson S, Morrison PJ, Walker L, Rogers MT, Donaldson A, Dorkins H, Godwin AK, Bove B, Stoppa-Lyonnet D, Houdayer C, Buecher B, de Pauw A, Mazoyer S, Calender A, Léoné M, Bressac-de Paillerets B, Caron O, Sobol H, Frenay M, Prieur F, Ferrer SU, Mortemousque I, Buys S, Daly M, Miron A, Terry MU, Hopper JL, John EM, Southey M, Goldgar D, Singer CF, Fink-Retter A, Tea MK, Kaulich DU, Hansen TV, Nielsen FC, Barkardottir RB, Gaudet M, KirchhoffT, Joseph V, Dutra-Clarke A, Offit K, Piedmonte M, Kirk J, Cohn D, Hurteau J, Byron J, Fiorica J, Toland AE, Montagna M, Oliani C, Imyanitov E, Isaacs C, Tihomirova L, Blanco I, Lazaro C, Teulé A, Valle JD, Gayther SA, Odunsi K, Gross J, Karlan BY, Olah E, Teo SH, Ganz PA, Beattie MS, Dorfling CM, van Rensburg EU, Diez O, Kwong A, Schmutzler RK, Wappenschmidt B, Engel C, Meindl A, Ditsch N, Arnold N, Heidemann S, Niederacher D, Preisler-Adams S, Gadzicki D, Varon-Mateeva R, Deissler H, Gehrig A, Sutter C, Kast K, Fiebig B, Schäfer D, Caldes T, de la Hoya M, Nevanlinna $H$, Muranen TA, Lespérance B, Spurdle AB, Neuhausen SL, Ding YC, Wang X, Fredericksen Z, Pankratz VS, Lindor NM, Peterlongo P, Manoukian S, Peissel B, Zaffaroni D, Bonanni B, Bernard L, Dolcetti R, Papi L, Ottini L, Radice P, Greene MH, Loud JT, Andrulis IL, Ozcelik H, Mulligan
AU, Glendon G, Thomassen M, Gerdes AM, Jensen UB, Skytte AB, Kruse TA, Chenevix-Trench G, Couch FJ, Simard J, Easton DF, CIMBA, SWE-BRCA, HEBON, EMBRACE, GEMO Collaborators Study, kConFab Investigators. Common variants at 12p11,12q24,9p21,9q31.2 and in ZNF365 are associated with breast cancer risk for BRCA1 and/or BRCA2 mutation carriers. Breast Cancer Res. 2012;14(1):R33. https://doi.org/10.1186/bcr3121.

29. Huret JL, Ahmad M, Arsaban M, Bernheim A, Cigna J, Desangles F, Guignard JC, Jacquemot-Perbal MC, Labarussias M, Leberre V, Malo A, Morel-Pair C, Mossafa H, Potier JC, Texier G, Viquié F, Yau Chun Wan-Senon S, Zasadzinski A, Dessen P. Atlas of genetics and cytogenetics in oncology and haematology in 2013. Nucl Acids Res. 2013;41(Database issue):920-4. https://doi.org/10.1093/nar/gks1082.

30. Fragomeni SM, Sciallis A, Jeruss JS. Molecular subtypes and local-regional control of breast cancer. Surg Oncol Clin N Am. 2018;27(1):95-120. https ://doi.org/10.1016/j.soc.2017.08.005.

31. Tang MH, Varadan V, Kamalakaran S, Zhang MQ, Dimitrova N, Hicks J. Major chromosomal breakpoint intervals in breast cancer co-localize with differentially methylated regions. Front Oncol. 2012;2:197. https://doi. org/10.3389/fonc.2012.00197.

32. Horlings HM, Lai C, Nuyten DS, Halfwerk H, Kristel P, van Beers E, Joosse SA, Klijn C, Nederlof PM, Reinders MJ, Wessels LF, van de Vijver MJ. Integration of DNA copy number alterations and prognostic gene expression signatures in breast cancer patients. Clin Cancer Res. 2010;16(2):651-63. https://doi.org/10.1158/1078-0432.CCR-09-0709.

33. Ye Y, Qiu TH, Kavanaugh C, Green JE. Molecular mechanisms of breast cancer progression: lessons from mouse mammary cancer models and gene expression profiling. Breast Dis. 2004;19:69-82. https://doi. org/10.3233/bd-2004-19109.

34. Guja K, Liehr T, Rincic M, Kosyakova N, Hussein Azawi SS. Molecular cytogenetic characterization identified the murine B-cell lymphoma cell line A-20 as a model for sporadic Burkitt's lymphoma. J Histochem Cytochem. 2017;65(11):669-77. https://doi.org/10.1369/0022155417731319.

35. Steinacker R, Liehr T, Kosyakova N, Rincic M, Azawi SS. Molecular cytogenetic characterization of two murine cancer cell lines derived from salivary gland. Biol Commun. 2019;63(4):243-55.

36. Tan Z, Chu ZV, Chan YJA, Lu YE, Rancati G. Mammalian cells undergo endoreduplication in response to lactic acidosis. Sci Rep. 2018;8(1):2890. https://doi.org/10.1038/s41598-018-20186-7.

37. International System for Human Cytogenomic Nomenclature 2016 (ISCN 2016). Eds: J. McGowan-Jordan J, Simons A; Schmid M; Karger: Basel, Switzerland, Unionville, USA, 2016.

\section{Publisher's Note}

Springer Nature remains neutral with regard to jurisdictional claims in published maps and institutional affiliations.

\footnotetext{
Ready to submit your research? Choose BMC and benefit from:

- fast, convenient online submission

- thorough peer review by experienced researchers in your field

- rapid publication on acceptance

- support for research data, including large and complex data types

- gold Open Access which fosters wider collaboration and increased citations

- maximum visibility for your research: over $100 \mathrm{M}$ website views per year
}

At $\mathrm{BMC}$, research is always in progress.

Learn more biomedcentral.com/submissions 